О.І. Сухаревський ${ }^{1}$, Г.С. Залевський ${ }^{1}$, В.О. Василець ${ }^{1}$, Ю.О. Галкін ${ }^{1}$, С.А. Горєлишев ${ }^{2}$, К.В. Садовий ${ }^{1}$

${ }^{1}$ Харківський національний університет Повітряних Сил ім. І. Кожедуба, Харків

${ }^{2}$ Начіональна академія Національної гвардї України, Харків

\title{
ХАРАКТЕРИСТИКИ ВТОРИННОГО ВИПРОМІНЮВАННЯ ТАКТИЧНОГО БЕЗПІЛОТНОГО ЛІТАЛЬНОГО АПАРАТУ У МЕТРОВОМУ, ДЕЦИМЕТРОВОМУ I САНТИМЕТРОВОМУ ДІАПАЗОНАХ ХВИЛЬ
}

Розглядаються результати комп'ютерного моделювання характеристик вторинного випромінювання (ХВВ) моделі тактичного безпілотного літального апарату (БпЛА) у метровому, дециметровому та сантиметровому діапазонах хвиль. Аналізуються конструктивні особливості тактичного БпЛА як вторинного випромінювача у різних діапазонах хвиль. Описано ичифрові моделі поверхонь елементів конструкції тактичного БпЛА. У залежності від електричних розмірів елементів конструкиї БпЛА для моделювання використовувались різні електродинамічні методи. Наводиться їх стислий опис. Демонструються діаграми зворотного вторинного випромінювання (ДЗВВ) БпЛА та окремих металевих $i$ діелектричних елементів його конструкиї у трьох діапазонах хвиль, на двох ортогональних поляризаціях. Аналізується вклад елементів конструкції у сумарний розсіяний сигнал. Проводиться порівняння медіанних значень ефективної поверхні розсіювання (ЕПР) у азимутальних секторах для моделі тактичного БпЛА, крилатої ракети та винищувача у метровому, дециметровому та сантиметровому діапазонах хвиль. Наведені дані дозволяють оцінити можливості радіолокаційних станиій (РЛС) різних частотних діапазонів щеодо виявлення і супроводження тактичних БпЛА.

Ключові слова: ефективна поверхня розсіювання, методи математичного моделювання, радіолокаційна помітність, тактичний безпілотний літальний апарат.

\section{Вступ}

Постановка проблеми. БПЛА різного призначення знаходять все більше застосування в у мовах сучасних гібридних війн [1]. Досвід радіолокаційного спостереження тактичних БпЛА вказує на складність їх виявлення та стійкого супроводження завдяки особливостям їх конструкції [2] та способам застосування. Радіолокація тактичних БпЛА ускладнена не тільки для РЛС старого парку, які ще на етапі розробки не призначались для виявлення таких об'єктів, але і для багатьох сучасних РЛС. Тактичний БпЛА є складним об'єктом радіолокації, який має низьку радіолокаційну помітність та може здійснювати переміщення на гранично малих висотах із невеликою швидкістю. У таких умовах радіолокація тактичного БпЛА ускладнена завдяки потужним відбиттям від земної поверхні. Навіть РЛС, що створено на сучасній елементній базі та у яких реалізовано цифрові алгоритми обробки, не спроможні впевнено виділяти корисний сигнал у таких складних умовах радіолокаційного спостереження.

Для підвищення показників якості виявлення тактичних БпЛА необхідно створювати нові спеціалізовані РЛС, а також проводити модернізацію існуючих, зокрема шляхом введення спеціальних алгоритмів і режимів роботи. У подальшому процесі створення (модернізації) важливо мати інформацію про особливості радіолокаційного розсіювання так- тичних БпЛА у різних діапазонах хвиль. По-перше, це забезпечить можливість обгрунтованого оцінювання оптимального діапазону частот, в якому може бути забезпеченим максимальний рівень сигналу, відбитого БПЛА. По-друге, відомі значення ЕПР шуканих об'єктів використовуються у спеціальному програмному забезпеченні моделювання бойових дій при оцінюванні ефективності РЛС різного призначення. По-третє, цю інформацію у подальшому доцільно використовувати в алгоритмах обробки сигналів, для більш ефективного виділення корисного сигналу на фоні шумів та пасивних завад. Почетверте, математичні моделі вторинного випромінювання БПЛА дозволяють оцінювати рівень вторинного випромінювання різних конструктивних варіантів на етапі розробки вітчизняних літальних апаратів 3 низькою радіолокаційною помітністю. Враховуючи зазначене вище, дослідження ХВВ БПЛА $є$ актуальною науково-технічною задачею.

Аналіз останніх досліджень і публікацій. Перспективним напрямкам підвищення ефективності радіолокації маловисотних малопомітних цілей присвячено значну кількість публікацій, зокрема [3-12]. У свою чергу, для підвищення ефективності ведення радіолокаційної розвідки тактичних БПЛА застосовується низка організаційних та технічних заходів $[4 ; 6 ; 10]$. Результати аналізу застосування засобів радіолокації, завданням яких було, у тому числі, виявлення малопомітних повітряних цілей у зоні 
проведення операції Об'єднаних Сил на сході України та у 2-й Карабаській війні, показують, що якісного підвищення результатів радіолокаційного спостереження тактичних БпЛА можливо досягти за рахунок створення перспективних (модернізації існуючих) РЛС, які будуть враховувати особливості радіолокаційних відгуків таких об'єктів.

Більшість відомих робіт присвячено дослідженню ХВВ квадрокоптерів (наприклад $[3 ; 5 ; 8])$. У роботах [11-12] описано електродинамічні методи моделювання ХВВ БпЛА різних електричних розмірів, конструкція яких містить металеві та діелектричні елементи. У цих роботах стисло описано особливості вторинного випромінювання моделі тактичного БПЛА у різних діапазонах хвиль. Роботу [7] присвячено фізичному моделюванню відгуків тактичного БпЛА у Х-діапазоні. Аналіз показує, що у відомій літературі відсутній достатній об'єм якісних i кількісних даних про ХВВ тактичних БпЛА для різних умов радіолокації, які б дозволили конкретизувати перспективні напрямки підвищення ефективності радіолокаційного спостереження таких об’єктів. Даний факт потребує проведення подальших досліджень, в основу яких може бути покладеним математичне моделювання.

Метою статті $\epsilon$ дослідження результатів комп'ютерного моделювання ХBВ тактичного БПЛА з метою оцінювання рівня радіолокаційної помітності об'єктів такого типу у різних діапазонах хвиль та порівняння ЕПР тактичного БПЛА і більш досліджених (стосовно вторинного випромінювання) повітряних цілей типу крилата ракета та винищувач.

\section{Виклад основного матеріалу}

\section{1. Аналіз конструкції тактичного БпЛА як вторинного випромінювача}

У різних діапазонах довжин хвиль тактичні БпЛА мають різні електричні розміри (відношення геометричного розміру до довжини хвилі). У дециметровому і метровому діапазонах характерні геометричні розміри тактичних БпЛА, співрозмірні із довжиною зондувальної хвилі. Тому вони $\epsilon$ об'єктами резонансних електричних розмірів (резонансними об'єктами). У сантиметровому діапазоні тактичні БПЛА можуть розглядатись як об'єкти великих електричних розмірів.

Для забезпечення високої точності розрахунку ЕПР у залежності від електричних розмірів об'єктів застосовують конкретні електродинамічні методи розрахунку.

Розглянемо тактичний БпЛА як джерело вторинного випромінювання у різних діапазонах довжин хвиль. Літальні апарати, що розглядаються, мають довжину фюзеляжу і розмах крил близько 2 м. Фюзеляж, крила і стабілізатори як правило ви- готовляються із діелектричного матеріалу і мають тонкі стінки (до 5 мм). Тому слід очікувати, що у метровому i дециметровому діапазонах фюзеляж тактичного БпЛА буде радіопрозорим, а основний вклад у сумарне розсіяне ним поле у даних діапазонах будуть вносити наступні складові: елементи 3 металевою поверхнею - рухова установка (двигун із глушником), блоки управління і корисного навантаження; діелектричні елементи - паливний бак, що має тонкі стінки, наповнений бензином, який як наслідок можна вважати однорідним діелектричним об’єктом із відповідною діелектричною проникністю бензину, а також гвинт. Геометричні розміри зазначених елементів різняться та складають від одиниць до десятків сантиметрів. Таким чином, тактичний БпЛА є об'єктом складної форми, що має металеві і діелектричні елементи конструкції. У метровому і дециметровому діапазонах хвиль тактичні БпЛА є об'єктами резонансних розмірів і тому для розрахунку їх ХВВ доцільно застосовувати методи, засновані на розв'язанні інтегральних рівнянь (IP) [12-15]. У сантиметровому діапазоні об'єкти, що розглядаються, а також окремі елементи конструкції - рухову установку, блоки управління і корисного навантаження, паливний бак, можна вважати електрично великими. Тому для моделювання ХВВ тактичних БпЛА у даному діапазоні доцільно застосовувати асимптотичні високочастотні методи (АВЧМ) [11; 13; 16-19]. Крім того, для підвищення точності розрахунку доцільно враховувати вклад електрично тонких діелектричних стінок конструкції БПЛА у сумарне розсіяне електромагнітне поле (ЕМП).

Не виключаються випадки, коли різні елементи конструкції тактичного БпЛА можуть належати до різних областей (релеєвської, резонансної і високочастотної). У цьому випадку для отримання високої точності обчислень і прийнятного часу на моделювання ХВВ доцільно застосовувати комбіновані методи, що передбачають, наприклад, застосування АВЧМ для розрахунку відгуків електрично великих елементів конструкції і методу, заснованого на розв'язанні IP, стосовно до компонентів, розміри яких належать до резонансної (релеєвської) області, 3 подальшим врахуванням електромагнітної взаємодії між зазначеними елементами конструкції. Зокрема такий метод описаний у роботах [18-19].

\section{2. Методи, що застосовувались для математичного моделювання}

\section{1. Елементи конструкції резонансних розмірів}

У роботі для моделювання ЕМП, розсіяних резонансними металевими елементами конструкції БпЛА, застосовувався електродинамічний метод розрахунку, що передбачає обчислення щільності 
електричного струму на поверхнях металевих розсіювачів шляхом розв'язання IP магнітного поля $[12 ; 15]$.

У випадку резонансних діелектричних елементів конструкції БпЛА застосовувався електродинамічний метод, заснований на розв'язанні системи IP Мюлера (СІРМ) для обчислення щільностей еквівалентних електричного і магнітного струмів на поверхні діелектричних розсіювачів [12;15].

ЕМП, розсіяне таким складним розсіювачем, як БпЛА, необхідно обчислювати із урахуванням електромагнітної взаємодії металевих і діелектричних елементів конструкції. Відгук БПЛА у метровому і дециметровому діапазонах хвиль може бути розрахованим як когерентна сума полів, розсіяних його металевими і діелектричними елементами конструкції. Проведені дослідження електромагнітної взаємодії окремих елементів конструкції літальних апаратів [12-15; 20-21] показують, що застосування такого методу забезпечує достатньо високу точність моделювання ХВВ БпЛА, які містять металеві і діелектричні елементи конструкції у метровому і дециметровому діапазонах хвиль.

Для більш детального врахування електромагнітної взаємодії металевих і діелектричних елементів конструкції БпЛА можуть застосовуватись ітераційні методи, один з яких описаний у роботах [2021]. У загальному випадку для точного врахування електромагнітної взаємодії різнорідних елементів конструкції БпЛА необхідно отримати відповідну систему IP. Застосування ітераційних методів, зокрема описаного у [20-21], та систем рівнянь, що описують щільності струмів на поверхнях реальних комбінованих об'єктів, пов'язані із значними часовими витратами і потрібними комп'ютерними ресурсами.

\section{2. Електрично великі елементи конструкції}

Електродинамічний метод розрахунку ХВВ електрично великих об'єктів (у тому числі повністю або частково покритих радіопоглинаючим покриттям) детально описано у роботах [18-19]. Запропонований АВЧМ базується на роздільному оцінюванні вкладів гладких частин поверхонь розсіювачів і крайових елементів у сумарне розсіяне ЕМП. Даний метод при моделюванні ХВВ БпЛА у сантиметровому діапазоні хвиль має свої особливості [11]. Відповідно до типової конструкції тактичного БпЛА для розрахунку його вторинного випромінювання у сантиметровому діапазоні хвиль необхідно розрахувати характеристики розсіяння ідеально провідних елементів, елементів обладнання, прихованих під діелектричною оболонкою фюзеляжу, а також порожнистих діелектричних елементів. Згідно розробленого алгоритму [11] окремо обчислюється розсіювання на діелектричній оболонці, до нього додається розсіювання на внутрішніх елементах БпЛА з урахуванням проходження ЕМП крізь діелектричну оболонку.

На основі описаних електродинамічних методів розроблено спеціальне програмне забезпечення, що дозволяє моделювати ХВВ БпЛА у різних діапазонах хвиль.

Розроблене математичне забезпечення на прикладах порівняно простих модельних об'єктів пройшло верифікацію із даними, отриманими іншими чисельними методами та результатами фізичного моделювання [15; 18].

\section{3. Моделі елементів конструкції тактичного БпЛА}

Важливою складовою частиною будь-якого методу розрахунку ХВВ об'єкта складної форми є моделі поверхонь його окремих елементів $[15 ; 18]$. Від ступеня деталізації цих поверхонь у значній мірі залежить точність остаточного результату. На підставі аналізу конструкцій декількох тактичних БПЛА створено узагальнену цифрову модель поверхонь окремих елементів такого об'єкта, яку зображено на рис. 1 [11-12]. Для апроксимації діелектричної оболонки було використано частки 36 тривісних еліпсоїдів. Відносна діелектрична проникність матеріалу оболонки складала $\varepsilon_{\partial}=3,2+i 0,07$. Матеріал, 3 якого виготовлено фюзеляж, крила, кіль і стабілізатори, вважався одношаровим діелектриком. Носова частина фюзеляжу, що вміщує двигун під обтічником, а також крила і стабілізатори були виконані iз пластику товщиною 1 мм. Середня і кормова частини фюзеляжу, у яких розміщалися паливний бак, блоки управління і корисного навантаження були виконані із пластику товщиною 2 мм.

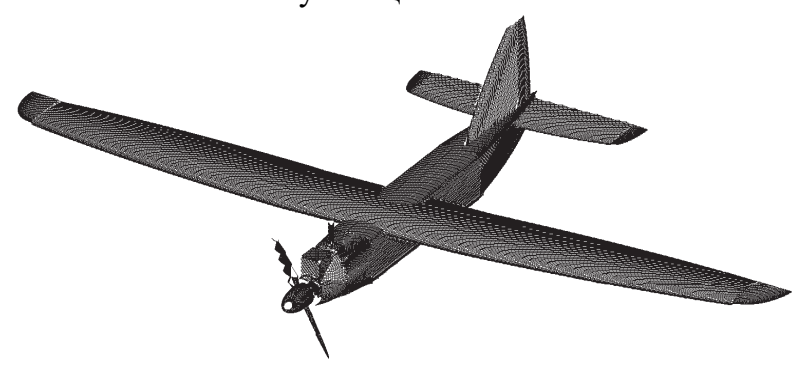

Рис. 1. Модель поверхні БпЛА Джерело: розроблено авторами.

Далі на рис. 2 наведено цифрові моделі окремих елементів конструкції БпЛА, а на рис. 3 і 4 детальний опис геометрії моделей. Розміри складових елементів вказано у міліметрах. Паливний бак при моделюванні розглядався, як однорідний діелектричний об'єкт з відносною діелектричною проникністю бензину $\varepsilon_{\partial}=2,3+i 0,03$. Модель гвинта являє собою однорідний діелектричний розсіювач із діелектричною проникністю $\varepsilon_{2}=2+i 0,03$.

Розроблена модель гвинта являє собою центра- 
льний циліндр з висотою 20 мм і діаметром підстави 46 мм та дві лопаті. Поверхня кожної лопаті апроксимована ділянками 4 еліпсоїдів (рис. 2 праворуч). Діаметр гвинта складає 52 мм.

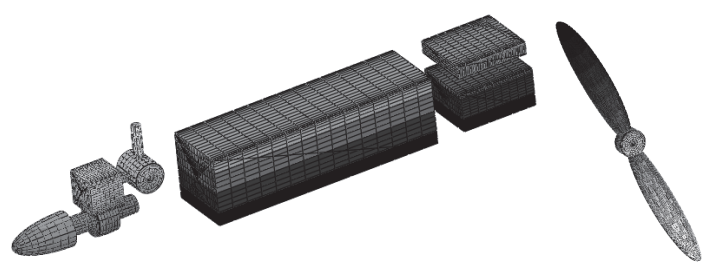

Рис. 2. Модель окремих елементів конструкції БпЛА Джерело: розроблено авторами.
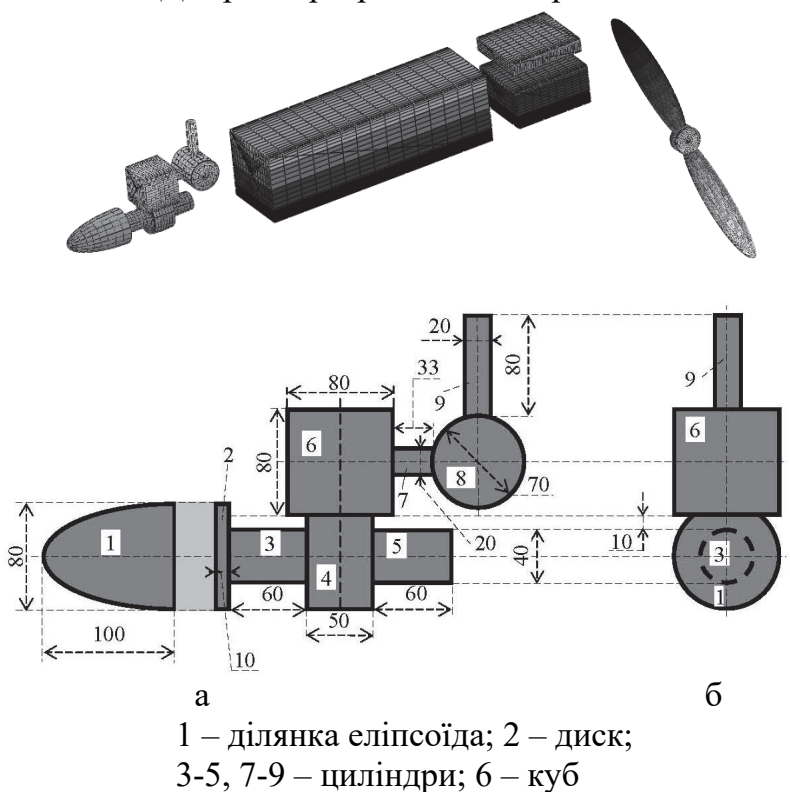

Рис. 3. Опис геометрії ідеально провідної моделі рухової установки БПЛА: а - вигляд збоку; б - вигляд спереду Джерело: розроблено авторами.
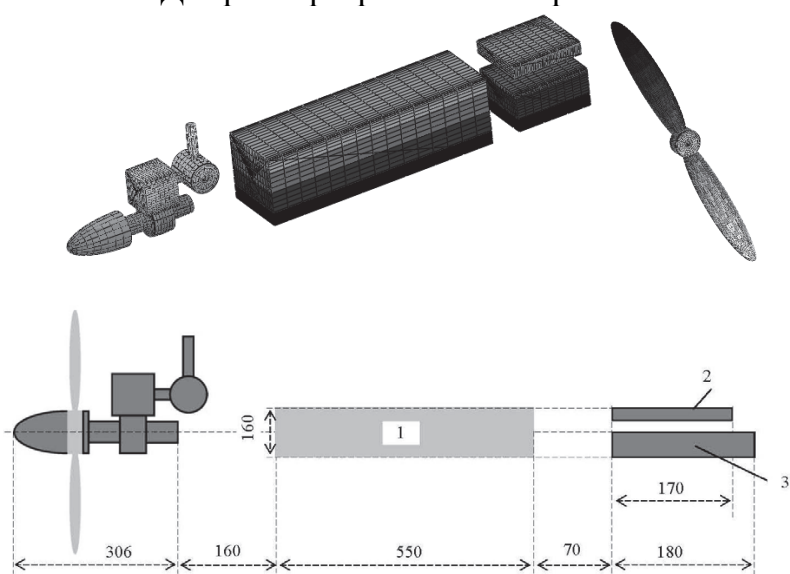

1 - паливний бак (ширина і висота 160 мм);

2 - блок управління ( ширина 150 мм, висота 30 мм);

3 - корисна вага (ширина 150 мм, висота 90 мм)

Рис. 4. Опис геометрії елементів конструкції БпЛА Джерело: розроблено авторами.

Необхідно відзначити, що характерні геометричні розміри елементів конструкції БпЛА співрозмірні з довжинами хвиль 30-10 см.

\section{4. Результати моделювання ХВВ тактичного БпЛА у різних діапазонах хвиль}

Моделювання ХВВ тактичного БпЛА проведено для трьох частот зондувального сигналу, що відповідають частотам: $f=180$ МГц (довжина хвилі $\lambda=1,67$ м, метровий діапазон), $f=3$ ГГц $(\lambda=10 \mathrm{~cm}$, дециметровий діапазон) і $f=10$ ГГц $(\lambda=3 \mathrm{~cm}$, сантиметровий діапазон).

За допомогою зазначених вище чисельних методів проведено розрахунок моностатичної ЕПР БпЛА б для заданих:

- ракурсів об'єкту відносно точки стояння РЛС у азимутальній (горизонтальній) і кутомісній (вертикальній) площинах, які характеризуються кутами

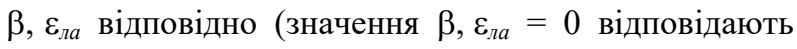
носовому ракурсу - зондуванню вздовж осі об'єкта, спереду, а $\beta=90$ град. - боковому ракурсу об'єкта);

- частоти зондувального сигналу $f$ (довжини хвилі $\lambda$ );

- поляризації зондувального сигналу (горизонтальній поляризації (ГП) відповідає зондувальний сигнал, вектор напруженості електричного поля $\vec{E}$ якого лежить у азимутальній площині, а при вертикальній поляризації (ВП) $\vec{E}$ орієнтований у кутомісній площині, перпендикулярно напрямку суміщених зондування і прийому).

Всі значення ЕПР наведено у квадратних метpax. При розрахунках ЕПР тактичного БпЛА на всіх частотах кут $\beta$ змінювався із кроком 0,1 град. Кожному фіксованому значенню $\beta$ відповідав випадковий кут місця, розподілений за рівномірним законом у діапазоні $\varepsilon_{л а}=-3 \pm 4$ град. (від'ємний кут місця $\varepsilon_{л а}$ відповідає зондуванню 3 нижньої півсфери). Таким чином враховано випадкові зміни ракурсу об'єкта у польоті, які мають місце на практиці.

Для розрахунку діаграм ЕПР БПЛА, модель якого подано на рис. 1-4, у метровому і дециметровому діапазоні довжин хвиль застосовувався метод, заснований на розв'язанні IP, описаний у роботах [12; 15]. Тонка діелектрична оболонка, 3 якої виконано фюзеляж, крила, стабілізатори і кіль, у метровому і дециметровому діапазонах довжин хвиль $є$ радіопрозорою, вносить незначний вклад у сумарне розсіяне ЕМП, і тому при моделюванні не враховувалась. На даному етапі також не враховувались кабелі. У даних частотних діапазонах основний вклад у розсіяне БПЛА ЕМП вносять рухова установка, блоки управління і корисного навантаження, а також паливний бак.

Для моделювання у сантиметровому діапазоні застосовувався АВЧМ, описаний у роботах $[11 ; 18-$ 19]. У даному випадку ЕМП, розсіяне БпЛА, розраховувалось як сумарне поле, розсіяне всіма елементами конструкції з урахуванням впливу тонкої діе- 
лектричної оболонки, що утворює фюзеляж, крила, стабілізатори і кіль.

Враховуючи електричні розміри гвинта, його ЕПР розраховувалась за допомогою методу, заснованого на розв'язанні СІРМ, описаного у [12; 15].

Діаграми ЕПР моделі тактичного БпЛА подано на рис. 5-7. На діаграмах ЕПР об'єкта на ГП зображені чорною тонкою, а на ВП - жирною сірою лініями. Наведені діаграми дозволяють судити про характер вторинного випромінювання розглянутої моделі БпЛА у трьох діапазонах хвиль.

У метровому діапазоні хвиль тактичний БпЛА має набагато менші значення ЕПР, ніж у дециметровому і сантиметровому діапазонах.

Як і очікувалось, при збільшенні частоти діаграми ЕПР стають більш зрізаними. При цьому зменшуються відмінності залежностей ЕПР від азимутального ракурсу на двох ортогональних поляризаціях.

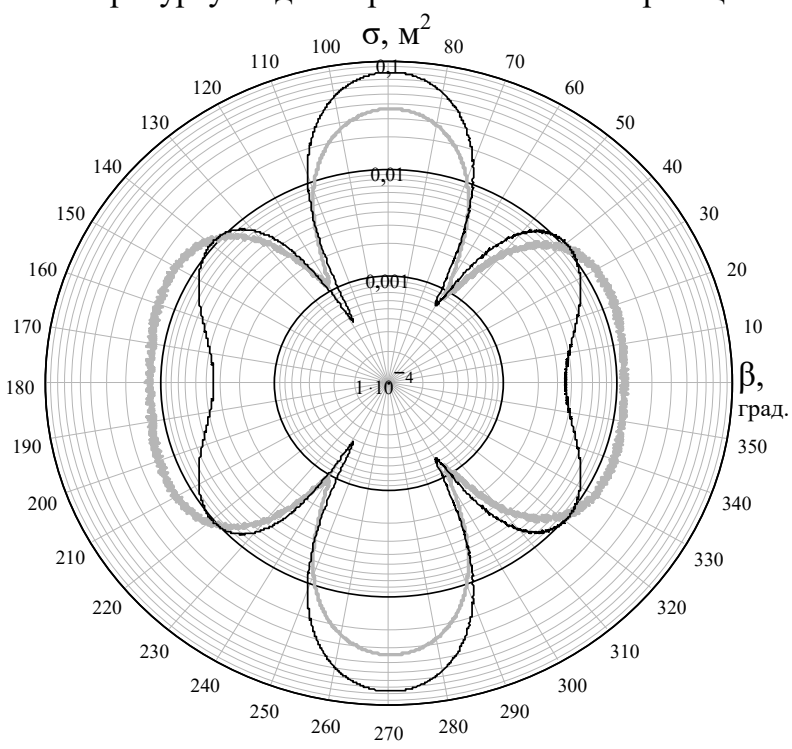

Рис. 5. ДЗВВ БпЛА при $f=180$ МГц

Джерело: розроблено авторами.

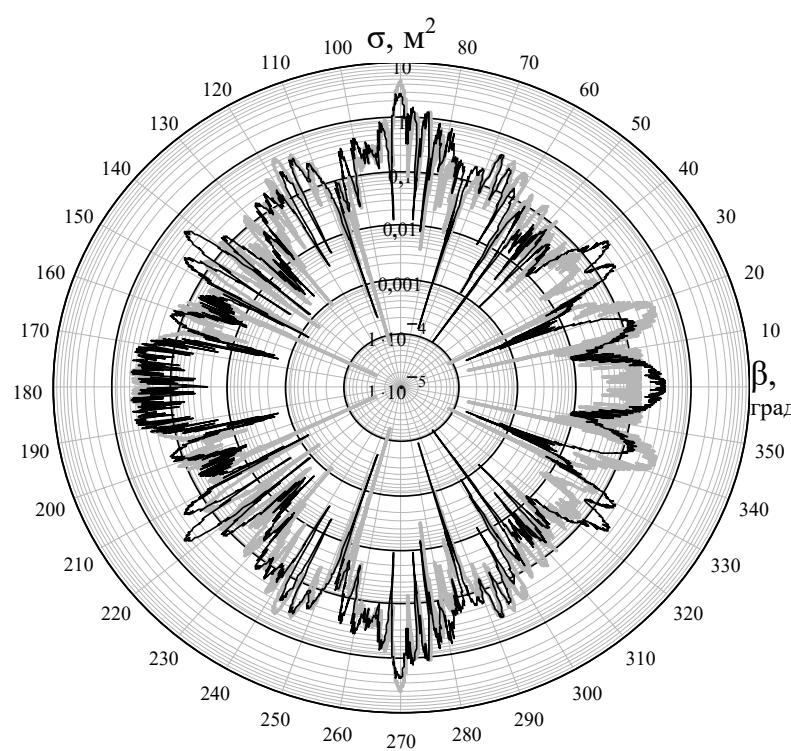

Рис. 6. ДЗВВ БпЛА при $f=3$ ГГц Джерело: розроблено авторами.

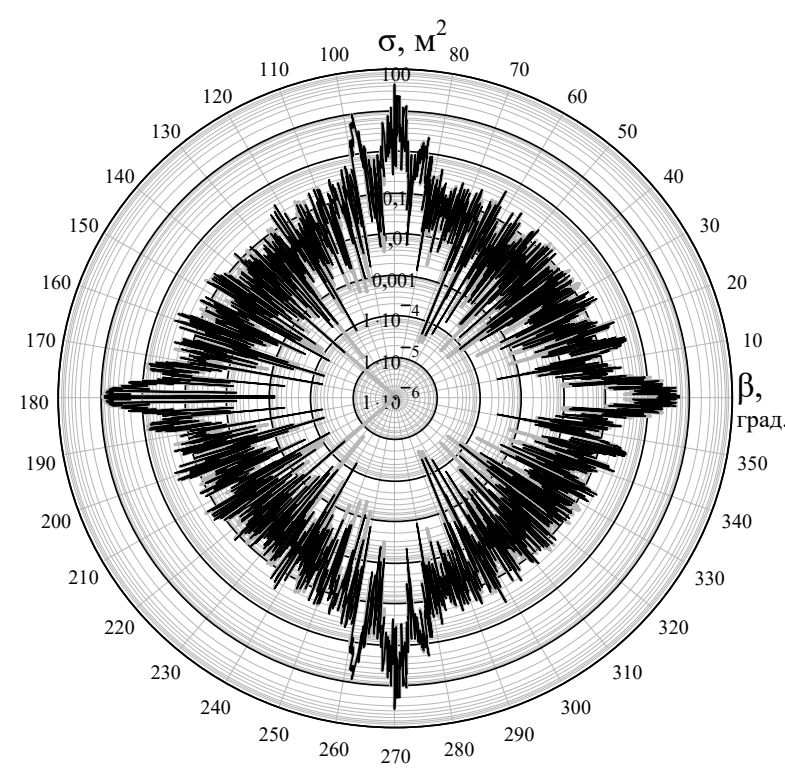

Рис. 7. ДЗВВ БпЛА при $f=10$ ГГц

Джерело: розроблено авторами.

Порівняння діаграм, наведених на рис. 5-7, вказує на те, що рівень вторинного випромінювання досліджуваного БПЛА у дециметровому і сантиметровому діапазонах більш ніж у 10 разів перевищує відповідний рівень у метровому діапазоні.

Інтенсивність вторинного випромінювання БПЛА у дециметровому та сантиметровому діапазонах одного порядку. Менша зрізаність діаграми ЕПР БпЛА у дециметровому діапазоні вказує на те, що відповідні РЛС можуть забезпечити більш стійке супроводження БпЛА у порівнянні з сантиметровим діапазоном.

За результатами моделювання ХВВ тактичного БПЛА у трьох різних діапазонах хвиль (метровому, дециметровому та сантиметровому) і на двох ортогональних поляризаціях, отримано статистичні оцінки його ЕПР. У якості таких характеристик вико-

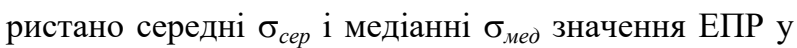
відповідних азимутальних секторах:

- круговий сектор $\left(\beta_{1}=0-360^{\circ}\right)$;

- носовий ракурс $\left(\beta_{2}=0 \pm 45^{\circ}\right)$;

- боковий ракурс $\left(\beta_{3}=45^{\circ}-135^{\circ} ; \beta_{3}=225^{\circ}-315^{\circ}\right)$;

- хвостовий ракурс $\left(\beta_{4}=135^{\circ}-225^{\circ}\right)$.

Отримані середні і медіанні значення ЕПР моделі тактичного БпЛА зведено у табл. 1-3 для метрового, дециметрового та сантиметрового діапазонів хвиль відповідно.

Розглянемо середні і медіанні значення ЕПР моделі тактичного БпЛА в трьох різних діапазонах. На частоті $f=3$ ГГц медіанні значення ЕПР БпЛА у 12-13 разів на ГП та у (4-14) разів на ВП перевищують аналогічні значення у метровому діапазоні при $f=180$ МГц.

У той же час медіанні значення ЕПР БПЛА при $f=3$ ГГц у 2-3 рази перевищують аналогічні значен- 
ня при $f=10$ ГГц, що відповідає сантиметровому діапазону.

Враховуючи низький рівень вторинного випромінювання БпЛА, його стійке виявлення і супроводження РЛС метрового діапазону хвиль ускладнене.

При більш детальному аналізі практично важливого носового ракурсу $\left(\beta_{2}=0 \pm 45\right.$ град.) слід відзначити, що більші середні значення ЕПР БПЛА у даному випадку відповідають сантиметровому діапазону. У той же час медіанні значення ЕПР БПЛА у дециметровому діапазоні перевищують аналогічні величини для сантиметрового діапазону. Такі величини середніх і медіанних ЕПР можна пояснити більшою зрізаністю діаграми ЕПР БПЛА у сантиметровому діапазоні хвиль.

Розглянемо ХВВ елементів конструкції тактичного БпЛА, що вносять максимальний вклад у сумарний відгук у метровому і дециметровому діапазоні хвиль. Наведені графіки дозволяють оцінити окремий вклад металевих елементів і діелектричного баку у сумарний відгук БпЛА.

Таблиця 1

Середні і медіанні значення ЕПР тактичного БпЛА у азимутальних секторах, у метровому діапазоні довжин хвиль $(f=180$ МГц, $\lambda=1,67$ м $)$

\begin{tabular}{|c|c|c|c|c|}
\hline \multirow{2}{*}{$\begin{array}{c}\text { Азимута- } \\
\text { льний } \\
\text { сектор }\end{array}$} & \multicolumn{4}{|c|}{ ЕП $\mathrm{\sigma}^{2}$} \\
\cline { 2 - 5 } & $\sigma_{\text {cep }}$ & $\sigma_{\text {мед }}$ & $\sigma_{\text {cep }}$ & $\sigma_{\text {мед }}$ \\
\hline$\beta_{1}$ & 0,0158 & 0,0074 & 0,0126 & 0,0120 \\
\hline$\beta_{2}$ & 0,0067 & 0,0064 & 0,0114 & 0,0118 \\
\hline$\beta_{3}$ & 0,0250 & 0,0091 & 0,0131 & 0,0071 \\
\hline$\beta_{4}$ & 0,0066 & 0,0061 & 0,0129 & 0,0130 \\
\hline
\end{tabular}

Джерело: розроблено авторами.

Таблиця 2

Середні і медіанні значення ЕПР тактичного БпЛА у азимутальних секторах, у дециметровому діапазоні довжин хвиль $(f=3$ ГГц, $\lambda=10 \mathrm{~cm})$

\begin{tabular}{|c|c|c|c|c|}
\hline \multirow{2}{*}{$\begin{array}{c}\text { Азимута- } \\
\text { льний } \\
\text { сектор }\end{array}$} & \multicolumn{4}{|c|}{$\mathrm{EПР,} \mathrm{m}^{2}$} \\
\cline { 2 - 5 } & $\sigma_{\text {cep }}$ & $\sigma_{\text {мед }}$ & $\sigma_{\text {cep }}$ & $\sigma_{\text {мед }}$ \\
\hline$\beta_{1}$ & 0,1666 & 0,0915 & 0,1708 & 0,0725 \\
\hline$\beta_{2}$ & 0,0987 & 0,0762 & 0,0859 & 0,0495 \\
\hline$\beta_{3}$ & 0,2198 & 0,1116 & 0,2421 & 0,0999 \\
\hline$\beta_{4}$ & 0,1282 & 0,0808 & 0,1129 & 0,0555 \\
\hline
\end{tabular}

Джерело: розроблено авторами.

Таблиця 3

Середні і медіанні значення ЕПР тактичного БПЛА у азимутальних секторах, у сантиметровому діапазоні довжин хвиль $(f=10$ ГГц, $\lambda=3$ см $)$

\begin{tabular}{|c|c|c|c|c|}
\hline \multirow{2}{*}{$\begin{array}{c}\text { Азимута- } \\
\text { льний } \\
\text { сектор }\end{array}$} & \multicolumn{4}{|c|}{ ЕПР, $\mathrm{m}^{2}$} \\
\cline { 2 - 5 } & $\sigma_{\text {cep }}$ & $\sigma_{\text {мед }}$ & $\sigma_{\text {cep }}$ & $\sigma_{\text {мед }}$ \\
\hline$\beta_{1}$ & 0,3965 & 0,0390 & 0,3928 & 0,0379 \\
\hline$\beta_{2}$ & 0,2377 & 0,0341 & 0,2334 & 0,0355 \\
\hline$\beta_{3}$ & 0,5143 & 0,0459 & 0,5005 & 0,0450 \\
\hline$\beta_{4}$ & 0,3197 & 0,0270 & 0,3365 & 0,0276 \\
\hline
\end{tabular}

Джерело: розроблено авторами.
На рис. 8 і 9 наведено діаграми ЕПР металевих елементів конструкції (чорна суцільна лінія) БпЛА (рухова установка, блоки управління та корисного навантаження) і паливного баку (сіра штрихова лінія) на двох ортогональних поляризаціях. Перелічені елементи конструкції вносять максимальний вклад у розсіяне БпЛА ЕМП. Дані, що наведені на рисунках нижче, відповідають частотам зондування $f=180$ МГц (рис. 8) і $f=3$ ГГц (рис. 9).

У метровому діапазоні ( $\lambda=1,67$ м) всі розглянуті елементи конструкції БпЛА мають достатньо малі електричні розміри. ЕПР діелектричного баку на порядок менша за ЕПР сукупності металевих елементів конструкції БпЛА, які визначають сумарну діаграму вторинного випромінювання.

Діаграма ЕПР металевих елементів має три максимуми. Їх вторинне випромінювання у даному діапазоні хвиль за характером близьке до “вібратоpy".

Форма діелектричного баку (паралелепіпед) визначає його діаграму ЕПР, яка має максимум при опроміненні перпендикулярно стінці бака.
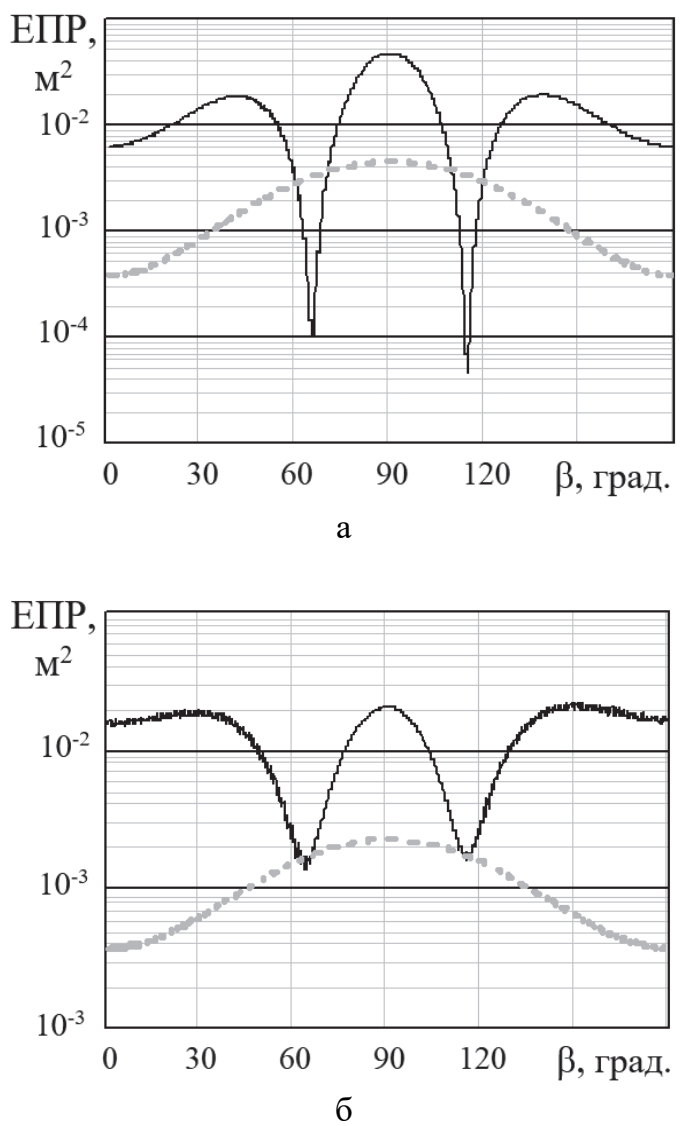

Рис. 8. ЕПР елементів конструкції БпЛА при $f=180$ МГц $(\mathrm{a}-$ ГП, б - ВП)

Джерело: розроблено авторами.

У дециметровому діапазоні ( $\lambda=10 \mathrm{~cm})$ всі елементи конструкції БПЛА $є$ резонансними розсіювачами. Рівень вторинного випромінювання металевих елементів і діелектричного баку співрозмірні. 


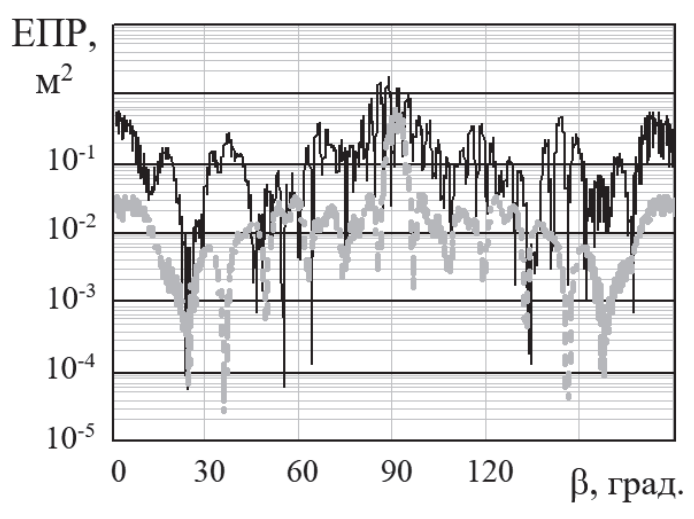

a

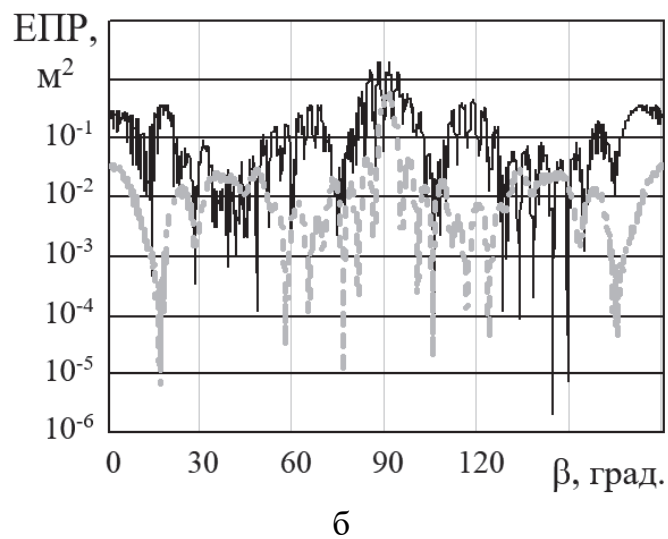

Рис. 9. ЕПР елементів конструкції БпЛА при $f=3$ ГГц (a - ГП, б - ВП)

Джерело: розроблено авторами.

У діаграмах спостерігається максимум інтенсивності вторинного випромінювання при $\beta=90$ град. ЕПР металевих елементів при азимутальних кутах, близьких до носового, лише незначно менша у порівнянні із боковим ракурсом. Локальні максимуми діаграми ЕПР паливного баку при носових і бокових ракурсах відрізняються більш суттєво.

Вклад металевих і діелектричних елементів конструкції БПЛА у сумарне ЕМП у сантиметровому діапазоні хвиль якісно збігається із даними для дециметрового діапазону.

Розрахунки ЕПР діелектричного гвинта БпЛА здійснювались в залежності від кута обертання $\alpha$ відносно осі БпЛА (рис. 10). Дані на рис. 11 і 12 відповідають напрямку суміщених опромінення і приймання вздовж осі БпЛА, а на рис. 13 напрямку зондування під кутом $\theta=30$ град. від осі гвинта.

Розрахунки проведено для частот 3 ГГц $\mathrm{i}$ 10 ГГц. У метровому діапазоні хвиль діелектричний гвинт, що обертається, має значно меншу ЕПР і може не враховуватись при моделюванні ХВВ тактичного БпЛА.

Результати моделювання отримано для двох ортогональних поляризацій:

ГП - вектор $\vec{E}$ орієнтований у площині обертання гвинта, (перпендикулярно лопатям гвинта при $\alpha=0$ і паралельно лопатям при $\alpha=90$ град.);
ВП - вектор $\vec{E}$ орієнтований у площині, утвореній віссю обертання гвинта і вектором, що вказує напрямок зондування, ортогонально цьому вектору.

Враховуючи, що на $f=3$ ГГц $(\lambda=10$ см $)$ поперечний розмір лопатей $(4,6$ см) достатньо малий, ЕПР гвинта при осьовому зондуванні приймає максимальні значення, коли вектор напруженості електричного поля зондувальної хвилі паралельний відрізку, що з'єднує кінці лопатей. При $f=10$ ГГц $(\lambda=3$ см) поперечний розмір лопатей співрозмірний із довжиною хвилі. Як наслідок, ЕПР гвинта приймає максимальні значення, коли кут між вектором напруженості електричного поля і відрізком, що з'єднує кінці лопаті, складає 10 град. Цей кут співпадає із кутом, на який повернені лопаті у площині обертання.

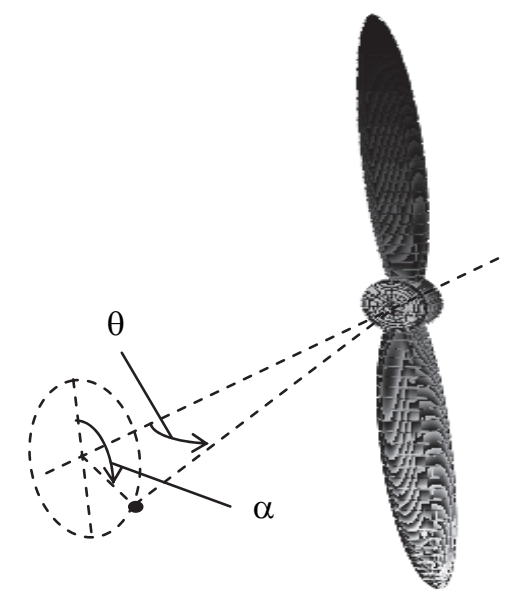

Рис. 10. Геометрія задачі при розрахунку ЕПР гвинта БпЛА Джерело: розроблено авторами.

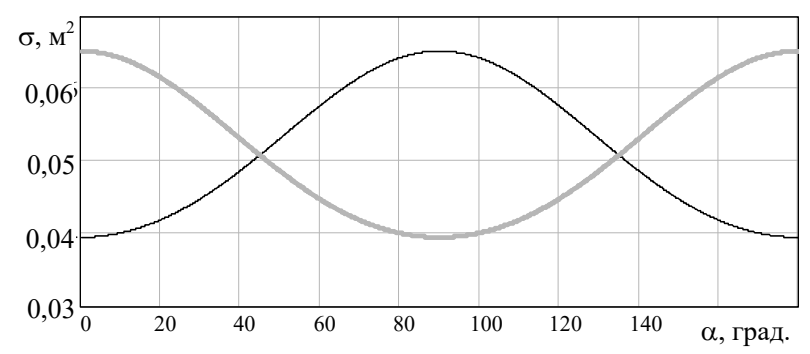

Рис. 11. ЕПР гвинта БпЛА при зондуванні уздовж його осі на $f=3$ ГГц Джерело: розроблено авторами.

При збільшенні кута спостереження $\theta$ (рис. 10), що відліковується від осьового напрямку, ЕПР гвинта падає (рис. 13).

Порівняння ЕПР гвинта (рис. 11-13) із ДЗВВ БпЛА для частот 3 ГГц (рис. 6) і 10 ГГц (рис. 7) показує, що у дециметровому і сантиметровому діапазонах при ракурсах БпЛА, близьких до носового, розглянутий діелектричний гвинт має ЕПР, порівняну із сумарною ЕПР решти елементів конструкції. Тому у даних частотних діапазонах гвинт доцільно враховувати при моделюванні ХВВ БпЛА. 


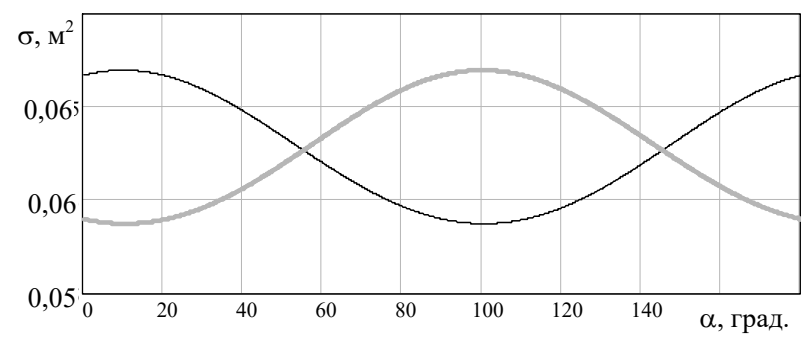

Рис. 12. ЕПР гвинта БпЛА

при зондуванні уздовж його осі на $f=10$ ГГц

Джерело: розроблено авторами.

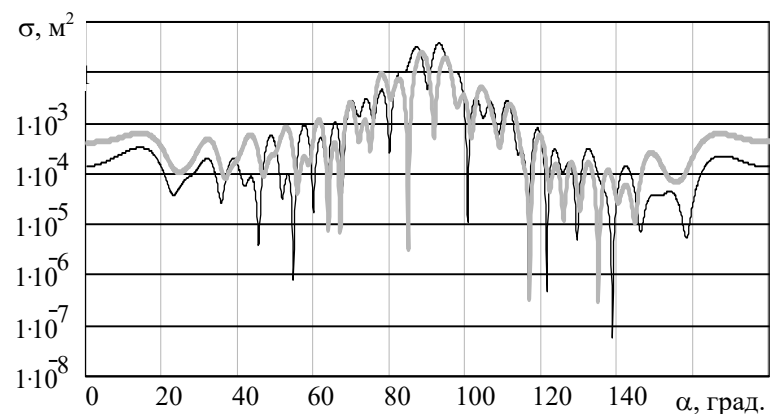

Рис. 13. ЕПР гвинта БпЛА при зондуванні під кутом $\theta=30$ град. від його осі на $f=10$ ГГц Джерело: розроблено авторами.

\section{5. Порівняння ЕПР тактичного БпЛА, крилатої ракети та винищувача}

Далі для кращого розуміння відносного рівня інтенсивності вторинного випромінювання тактичного БПЛА у роботі медіанні значення його ЕПР $\left(\sigma_{\text {мед БпЛА }}\right)$ порівнюються із аналогічними даними для

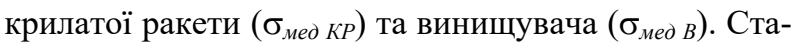
тистичні оцінки ЕПР крилатої ракети AGM86C у дециметровому і сантиметровому діапазонах хвиль та винищувача Міг-29 у трьох діапазонах хвиль, отриманих за допомогою АВЧМ [18], наведено у довіднику [19]. Медіанні значення ЕПР крилатої ракети у метровому діапазоні отримано за допомогою методу, заснованого на розв'язанні ІРМП [15]. Розраховані для частот 180 МГц, 3 ГГц і 10 ГГц відношення медіанних значень ЕПР наведено у табл. 4-5.

Таблиця 4

Відношення медіанних значень ЕПР БПЛА і крилатої ракети AGM86C у азимутальних секторах

\begin{tabular}{|c|c|c|c|c|c|c|}
\hline \multirow{4}{*}{$\begin{array}{c}\text { Азимута- } \\
\text { льний } \\
\text { сектор }\end{array}$} & \multicolumn{6}{|c|}{$\sigma_{\text {мед КР }} / \sigma_{\text {мед БиЛА }}$} \\
\hline & \multicolumn{3}{|c|}{ ГП } & \multicolumn{3}{|c|}{ ВП } \\
\hline & \multicolumn{3}{|c|}{ частота $f, \Gamma Г ц$} & \multicolumn{3}{|c|}{ частота $f, \Gamma Г ц$} \\
\hline & 0,18 & 3 & 10 & 0,18 & 3 & 10 \\
\hline$\beta_{1}$ & 1218 & 1,093 & 1,795 & 160,0 & 1,241 & 1,847 \\
\hline$\beta_{2}$ & 1781 & 0,131 & 0,293 & 197,5 & 0,202 & 0,282 \\
\hline$\beta_{3}$ & 415,4 & 2,957 & 4,793 & 226,8 & 3,704 & 5,111 \\
\hline$\beta_{4}$ & 1770 & 1,114 & 2,222 & 252,3 & 1,441 & 2,174 \\
\hline
\end{tabular}

Джерело: розроблено авторами.
Таблиця 5

Відношення медіанних значень ЕПР БпЛА

і винищувача Міг-29 у азимутальних секторах

\begin{tabular}{|c|c|c|c|c|c|c|}
\hline \multirow{4}{*}{$\begin{array}{c}\text { Азимута- } \\
\text { льний } \\
\text { сектор }\end{array}$} & \multicolumn{6}{|c|}{$\sigma_{\text {мед } B} / \sigma_{\text {мед БиЛА }}$} \\
\hline & \multicolumn{3}{|c|}{$\Gamma \Pi$} & \multicolumn{3}{|c|}{$\mathrm{B \Pi}$} \\
\hline & \multicolumn{3}{|c|}{ частота $f, \Gamma \Gamma ц$} & \multicolumn{3}{|c|}{ частота $f$, ГГц } \\
\hline & 0,18 & 3 & 10 & 0,18 & 3 & 10 \\
\hline$\beta_{1}$ & 806,8 & 16,94 & 39,74 & 535,0 & 21,38 & 42,22 \\
\hline$\beta_{2}$ & 801,6 & 22,05 & 50,73 & 200,0 & 33,94 & 49,86 \\
\hline$\beta_{3}$ & 1187 & 21,95 & 47,93 & 2423 & 24,53 & 49,33 \\
\hline$\beta_{4}$ & 445,9 & 9,406 & 29,63 & 548,5 & 13,69 & 30,44 \\
\hline
\end{tabular}

Джерело: розроблено авторами.

Наведені дані показують, що у метровому діапазоні хвиль медіанні значення ЕПР БПЛА у азимутальних секторах, що розглядаються, у 415-1780 разів на ГП та у 160-250 на ВП менші за аналогічні значення для крилатої ракети. У інших діапазонах хвиль різниця медіанних ЕПР менш суттєва. А у практично важливому носовому секторі $\left(\beta_{2}=0 \pm 45^{\circ}\right)$ медіанні ЕПР БпЛА перевищують відповідні величини для крилатої ракети при $f=3$ ГГц у 7,6 (ГП) і 5 (ВП) разів, а при $f=10$ ГГц приблизно у 3,4-3,55 рази.

У метровому діапазоні хвиль медіанні значення ЕПР тактичного БПЛА у 446-1187 разів на ГП та у 200-2423 рази на ВП менші у порівнянні з винищувачем. У дециметровому і сантиметровому діапазонах хвиль аналогічні відношення у залежності від азимутального сектору і поляризації складають 9-50 разів. Найменша різниця медіанних значень ЕПР БпЛА і винищувача спостерігається у дециметровому діапазоні хвиль. Відношення $\sigma_{\text {мед в }} / \sigma_{\text {мед БплА }}$ складає 9,4-22 на ГП та $13,7-33,9$ на ВП.

У випадку радіолокаційного спостереження тактичного БпЛА зменшена у порівнянні з крилатою ракетою та винищувачем ЕПР при інших незмінних умовах призводить до погіршення відношення "сигнал-шум” на вході приймача радіолокатору, що у свою чергу обумовлює зменшення дальності виявлення БпЛА у порівнянні $з$ двома іншими об'єктами та точності вимірювання його координат [17]. При всіх інших рівних умовах дальність виявлення розглянутого тактичного БпЛА у метровому діапазоні хвиль буде меншою у 4,6-5,9 (ГП) та у 3,8-7 (ВП) разів у порівнянні із винищувачем.

У дециметровому діапазоні хвиль дальність виявлення БпЛА зменшиться у порівнянні із винищувачем у 1,75-2,2 (ГП) та 1,9-2,4 (ВП) рази, а у сантиметровому у $2,3-2,7$ рази.

За рахунок зменшення відношення “сигналшум" погіршиться точність вимірювання координат тактичного БпЛА. При інших незмінних умовах у порівнянні з винищувачем збільшення середньоквадратичної похибки вимірювання координат може досягати до $49,5,8$ та 1,6 рази у метровому, дециметровому і сантиметровому діапазонах хвиль відповідно.

Слід відзначити, що наведені оцінки зменшення 
дальності виявлення і точності вимірювання координат тактичних БпЛА отримано для ідеальних умов вільного простору. У реальній радіолокаційній обстановці на показники якості радіолокаційного спостереження тактичних БпЛА як малошвидкісних малопомітних об'єктів суттєво впливають пасивні завади.

Отримані дані математичного моделювання ХВВ БпЛА, зокрема наведені у статті, свідчать про певні переваги застосування для радіолокаційного спостереження тактичних БпЛА зондувальних сигналів із довжиною хвилі 10-30 см. Особливо даний факт стосується практично важливого сектору азимутальних ракурсів, близьких до носового. Це пояснюється резонансним характером вторинного випромінювання БпЛА у даному діапазоні хвиль.

Слід відзначити, що дані математичного моделювання ХВВ снарядів артилерії і ракетних систем залпового вогню (РСЗВ), наведені у статті [22], також свідчать про переваги застосування сигналів із довжиною хвилі 10-30 см для зондування таких об'єктів.

Враховуючи вказані дані математичного моделювання, особливості застосування тактичних БпЛА та РЛС контрбатарейної боротьби, можна зробити висновок про доцільність поєднання функцій радіолокаційного спостереження таких БпЛА на невеликій висоті та снарядів артилерії і РСЗВ у мобільних РЛС дециметрового діапазону. Крім того, ряд українських і закордонних радіолокаторів даного типу ([22]) використовують зондувальні сигнали саме цього діапазону довжин хвиль 10-30 см.

\section{Висновки}

У статті розглянуто результати комп'ютерного моделювання ХВВ тактичного БПЛА у метровому, дециметровому та сантиметровому діапазонах хвиль. У залежності від електричних розмірів елементів конструкції БпЛА для моделювання застосовувались два різні електродинамічні методи.

У метровому і дециметровому діапазоні хвиль, у яких електричні розміри конструкційних елементів БпЛА відносяться до резонансної (у деяких випадках до релеївської) області для моделювання застосовувались методи, що базуються на розв'язанні IP [12; 15]. При цьому із достатньою для практики точністю при розрахунках у метровому і дециметровому діапазонах хвиль тонку діелектричну оболонку, яка утворює планер БпЛА, можна вважати радіопрозорою. У цьому випадку електромагнітний відгук БпЛА розраховується як суперпозиція ЕМП, розсіяних елементами конструкції БПЛА (рухова установка, блоки управління і корисного навантаження, паливний бак, гвинт), які дають основний вклад у сумарний сигнал.

У сантиметровому діапазоні хвиль розглянутий БПЛА можна вважати об'єктом електрично великих розмірів. I тому у цьому випадку для моделювання застосовувався АВЧМ [11; 18-19], згідно якого обчислюється ЕМП, розсіяне діелектричною оболон- кою. До цього додаються ЕМП, розсіяні внутрішніми елементами БПЛА з урахуванням проходження ЕМП крізь діелектричну оболонку.

Діелектричний гвинт розглянутого БпЛА має резонансні розміри у дециметровому і сантиметровому діапазонах хвиль. Тому для розрахунку його ХВВ застосовувався метод, заснований на розв'язанні СІРМ.

У роботі наведено ДЗВВ, середні та медіанні значення розглянутої моделі тактичного БпЛА та окремих його конструктивних елементів.

Наведені результати моделювання вказують на порівняно малий рівень вторинного випромінювання БпЛА у метровому діапазоні хвиль. Тому РЛС даного діапазону доцільно застосовувати лише для отримання додаткової інформації про такі малопомітні об'єкти.

Аналіз ДЗВВ і медіанних ЕПР БПЛА, зокрема у секторі азимутальних ракурсів, близьких до носового, вказують на певні переваги застосування для їх радіолокації сигналів дециметрового діапазону хвиль. Враховуючи отримані дані та беручи до уваги результати математичного моделювання ХВВ снарядів артилерії і РСЗВ, які також мають порівняно високий рівень вторинного випромінювання у дециметровому діапазоні [22], можна зробити висновок про доцільність поєднання функцій радіолокаційного спостереження таких резонансних об'єктів, як тактичні БпЛА на невеликій висоті і снаряди артилерії та РСЗВ у мобільній РЛС дециметрового діапазону із довжинами хвиль зондувального сигналу 10-30 см.

Результати моделювання показують, що амплітуда відгуку діелектричного гвинта у дециметровому і сантиметровому діапазонах хвиль швидко падає при відхиленні напрямку зондування від осьового. Разом із цим інтенсивність відбиття від гвинта $\epsilon$ співрозмірною із відгуками інших елементів конструкції БпЛА. У подальшому доцільно дослідити спектри гвинтової модуляції гвинта для різних умов радіолокації та проаналізувати можливість застосування інформації про параметри цих спектрів для ідентифікації БпЛА на фоні пасивних завад.

Отримані результати доцільно використовувати:

- при розробці практичних рекомендацій щодо створення перспективних вітчизняних радіолокаторів виявлення маловисотних малопомітних цілей;

- при розробці перспективних вітчизняних БпЛА із низьким рівнем радіолокаційної помітності;

- при розробці і удосконаленні способів підвищення ефективності радіолокаційного виявлення і супроводження цілей, що розглядаються;

- при оцінюванні можливостей існуючих і перспективних РЛС щодо виявлення і супроводження тактичних БпЛА.

Подальшою перспективою проведення подібних досліджень є збір, систематизація та узагальнення інформації про ХВВ БпЛА різних типів, при різних умовах радіолокації. Дослідження особливостей вторинного випромінювання БпЛА дозволить 
підвищити ефективність пристроїв і алгоритмів обробки відбитих ними сигналів на фоні пасивних завад. 3 цією метою доцільно проводити математичне моделювання процесу радіолокаційного спостере- ження БПЛА з урахуванням характеристик антенних систем РЛС, часово-частотних параметрів зондувальних сигналів, а також впливу пасивних завад різного походження.

\section{Список літератури}

1. Сучасне озброєння і військова техніка Збройних сил Російської Федерації. Довідник учасника ООС / за ред. С. П. Корнійчука. Харків : ДІСА ПЛЮС, 2020. 1220 с.

2. Markarian G., Staniforth A. Countermeasures for Aerial Drones. Boston, London : Artech House, 2021. 350 p.

3. Ritchie M., Fioranelli F., Griffiths H. Micro-drone RCS analysis. Proc. IEEE Radar Conference. Johannesburg, South Africa, 2015. P. 452-456.

4. Вишневський С. Д., Бейліс Л. В., Климченко В. Й. Потенційні можливості РЛС РТВ з виявлення оперативнотактичних та тактичних безпілотних літальних апаратів. Наука і техніка Повітряних Сил Збройних Сил Украйни. 2017. № 2(27). C. 92-98. https://doi.org/10.30748/nitps.2017.27.18.

5. Patel J., Fioranelli F., Anderson D. Review of radar classification and RCS characterisation techniques for small UAVs or drones. IET Radar, Sonar \& Navigation. 2018. No. 12(9). P. 911-919. https://doi.org/10.1049/iet-rsn.2018.0020.

6. Дудуш А. С., Тютюнник В. О., Резніченко О. А., Гогонянц С. Ю. Сучасний стан та проблеми протидії маловисотним, низькошвидкісним та малорозмірним БПЛА. Сучасні інформаційні технології у сфері безпеки та оборони. 2018. № 1. C. 121-131. https://doi.org/10.33099/2311-7249/2018-31-1-121-131.

7. Laučys A., Rudys S., Kinka M. Low-altitude UAV air ground propagation channel measurement and analysis in a suburban environment at $3.9 \mathrm{GHz}$. Aviation. 2019. No. 23(2). P. 48-53. https://doi.org/10.1049/iet-map.2019.0067.

8. Gong J., Yan J., Li D. Interference of radar detection of drones by birds. Progress in electromagnetics research. 2019. No. 81. P. 1-11. https://doi.org/10.1109/TAES.2018.2856338.

9. Riabukha V. Radar surveillance of unmanned aerial vehicles (review). Radioelectronics communication system. 2020. No. 63(11). P. 561-573. https://doi.org/10.3103/S0735272720110011.

10. Камалтинов Г. Г., Колеснік О. М. Тенденції розвитку радіолокаційних засобів контролю повітряного простору. Збірник наукових прачь Харківського начіонального університету Повітряних Сил. 2020. №2(64). С. 89-95. https://doi.org/ 10.30748/ zhups.2020.64.13.

11. Sukharevsky O., Vasilets V., Orlenko V., Ryapolov I. Radar Scattering Characteristics of a UAV Model in X-band. IET Radar, Sonar \& Navigation. 2020. Vol. 14. No. 4. P. 532-537. https://doi.org/10.1049/iet-rsn.2019.0243.

12. Zalevsky G., Sukharevsky O., Vasilets V. Integral equation modelling of unmanned aerial vehicle radar scattering characteristics in VHF to S frequency bands. IET Microwaves, Antennas \& Propagation. 2021. Vol. 15. No. 10. P. 1299-1309. http://doi.org/10.1049/mia2.12164.

13. Gibson W. The Method of Moments in Electromagnetics. Boca Raton, London, New York : Chapman \& Hall, Taylor \& Francis Group, 2008. 288 p.

14. Volakis J., Sertel K. Integral Equation Methods for Electromagnetics. Raleigh, NC, USA : SciTech Publishing, Inc., 2012. $391 \mathrm{p}$.

15. Sukharevsky O., Zalevsky G., Vasilets V. Modeling of Ultra wideband (UWB) Impulse Scattering by Aerial and Subsurface Resonant Objects Based on Integral Equation Solving. Advanced Ultra wideband Radar: Signals, Targets, and Applications / J. D. Taylor ed. Boca Raton London New York, 2016. P. 195-235. https://doi.org/10.1201/9781315374130.

16. Knott E., Shaeffer J., Tuley M. Radar Cross Section. $2^{\text {nd }}$ ed. Boston, London : Artech House, 1993. 611 p.

17. Радиоэлектронные системы: Основы построения и теория. Справочник / под ред. Я. Д. Ширмана. Москва : Радиотехника, 2007. $512 \mathrm{c}$.

18. Рассеяние электромагнитных волн воздушными и наземными радиолокационными объектами: монография / Сухаревский О. И. и др. Харьков : ХУВС, 2009. 468 с.

19. Сухаревський О. І., Василець В. О., Нечитайло С. В. Довідник характеристик розсіювання повітряних та наземних радіолокаційних об'єктів. Харків : ХНУПС ім. І. Кожедуба, 2019. 304 с.

20. Залевский Г. С., Бречка М. М., Василец В. А., Сухаревский О. И. Комбинированный метод расчета характеристик рассеяния объектов сложной формы и его применение для моделирования спектров винтовой модуляции вертолетов. Системи обробки інформації. 2014. № 4(120). С. 80-85.

21. Sukharevsky O. I., Zalevsky G. S., Vasilets V. A. Iterative Algorithm for Simulation of EM Scattering by Objects, Contained Constructive Elements of Different Electric Sizes. 2017 XXII International Seminar/Workshop on Direct and Inverse Problems of Electromagnetic and Acoustic Wave Theory (DIPED) : conference paper. IEEE, 2017. P. 190. https://doi.org/10.1109/ DIPED.2017.8100596193.

22. Залевський Г. С., Сухаревський О. І., Василець В. О., Сургай М. В. Оцінювання характеристик радіолокаційного розсіювання артилерійських снарядів у метровому, дециметровому і сантиметровому діапазонах довжин хвиль. Известия вузов. Радиоэлектроника. 2019. Т. 62. № 7. C. 427-442. https://doi.org/ 10.20535/S0021347019070033.

\section{Відомості про авторів:}

\section{Сухаревський Олег Ілліч}

доктор технічних наук професор

провідний науковий співробітник

Харківського національного університету

Повітряних Сил ім. І. Кожедуба,

Харків, Україна

https://orcid.org/0000-0002-4607-5361

\author{
Information about the authors: \\ Oleg Sukharevsky \\ Doctor of Engineering Science Professor \\ Leading Researcher \\ of Ivan Kozhedub Kharkiv National \\ Air Force University, \\ Kharkiv, Ukraine \\ https://orcid.org/0000-0002-4607-5361
}


Залевський Геннадій Станіславович

доктор технічних наук старший науковий співробітник професор кафедри Харківського національного університету Повітряних Сил ім. І. Кожедуба, Харків, Україна https://orcid.org/0000-0002-6173-0571

Василець Віталій Олексійович доктор технічних наук старший науковий співробітник провідний науковий співробітник

Харківського національного університету

Повітряних Сил ім. І. Кожедуба

Харків, Україна

https://orcid.org/0000-0002-3614-559X

\section{Галкін Юрій Олександрович}

викладач кафедри

Харківського національного університету

Повітряних Сил ім. І. Кожедуба,

Харків, Україна

https://orcid.org/0000-0002-9280-9645

Горєлишев Станіслав Анатолійович

кандидат технічних наук доцент

старший науковий співробітник

Національної академії Національної гвардії України,

Харків, Україна

https://orcid.org/0000-0003-1689-0901

Садовий Костянтин Віталійович

кандидат технічних наук доцент

заступник начальника кафедри

Харківського національного університету

Повітряних Сил ім. І. Кожедуба,

Харків, Україна

https://orcid.org/0000-0003-2703-9696
Gennady Zalevsky

Doctor of Engineering Science Senior Researcher

Professor of Department of Ivan Kozhedub Kharkiv

National Air Force University,

Kharkiv, Ukraine

https://orcid.org/0000-0002-6173-0571

Vitaly Vasilets

Doctor of Engineering Science Senior Researcher

Leading Researcher

of Ivan Kozhedub Kharkiv National

Air Force University,

Kharkiv, Ukraine

https://orcid.org/0000-0002-3614-559X

\section{Yurii Galkin}

Lecturer

of Ivan Kozhedub Kharkiv National

Air Force University,

Kharkiv, Ukraine

https://orcid.org/0000-0002-9280-9645

Stanislav Horielyshev

$\mathrm{PhD}$ in Engineering Associate Professor

Senior Researcher

of National Academy of National Guard of Ukraine,

Kharkiv, Ukraine

https://orcid.org/0000-0003-1689-0901

Kostiantyn Sadovyi

$\mathrm{PhD}$ in Engineering Associate Professor

Deputy Head of Department

of Ivan Kozhedub Kharkiv National

Air Force University,

Kharkiv, Ukraine

https://orcid.org/0000-0003-2703-9696

\title{
ХАРАКТЕРИСТИКИ ВТОРИЧННОГО ИЗЛУЧЕНИЯ ТАКТИЧЕСКОГО БЕСПИЛОТНОГО ЛЕТАТЕЛЬНОГО АППАРАТА В МЕТРОВОМ, ДЕЦИМЕТРОВОМ И САНТИМЕТРОВОМ ДИАПАЗОНАХ ВОЛН
}

\author{
О.І. Сухаревський, Г.С. Залевський, В О. Василець, Ю.О. Галкін, С.А. Горєлишев, К.В. Садовий
}

Рассматриваются результаты компьютерного моделирования характеристик вторичного излучения тактического беспилотного летательного аппарата (БЛА) в метровом, дециметровом и сантиметровом диапазонах волн. Анализируются конструктивные особенности тактического БЛА как вторичного излучателя в разных диапазонах волн. Описаны иифровые модели поверхностей элементов конструкции тактического БЛА. В зависимости от электрических размеров элементов конструкиии БЛА для моделирования использовались различные электродинамические методы. Приводится их краткое описание. Демонстрируются диаграммы обратного вторичного излучения БЛА и отдельных металлических и диэлектрических элементов его конструкиии в трех диапазонах волн, на двух ортогональных поляризаииях. Анализируется вклад элементов конструкции в суммарный рассеянный сигнал. Проводится сравнение медианных значений эффективной поверхности рассеяния в азимутальных секторах для модели тактического БЛА, крылатой ракеты и истребителя в метровом, дециметровом и сантиметровом диапазонах волн. Приведенные данные позволяют оценить возможности радиолокачионных станций разных частотных диапазонов по обнаружению и сопровождению тактических БЛА.

Ключевые слова: методы математического моделирования, радиолокационная заметность, тактический беспилотный летательный аппарат, эффективная поверхность рассеивания.

\section{RADAR SCATTERING CHARACTERISTICS}

\section{OF TACTICAL UNMANNED AERIAL VEHICLE IN VHF, S AND X FREQUENCY BANDS}

O. Sukharevsky, G. Zalevsky, V. Vasilets, Yu. Galkin, S. Horielyshev, K. Sadovyi

Results of computer modeling the radar scattering characteristics of tactical unmanned aerial vehicle (UAV) in VHF, S and X frequency bands are considered. Peculiarities of tactical UAV design as a secondary radiator in various frequency bands were analyzed. Digital models of tactical UAV structural components surfaces were described. Various electrodynamic methods were used for modeling depending on electrical sizes of UAV structural components. In the paper their brief description is presented. Back scattering diagrams for UAV and its single metallic and dielectric structural elements are demonstrated for three frequency bands and on two orthogonal polarizations. Contribution of structural elements to a total scattered signal was analyzed. Comparison of median values of radar cross section in azimuthal sectors for tactical UAV model, cruise missile and fighter was carried out for $V H F, S$ and X frequency bands. Obtained mathematical modeling results show that in the VHF frequency band the stable radar detection and tracking of tactical UAVs are complicated due to their comparatively low radar visibility. At the other hand numerical results confirm advantages of using an S-band probing signals for such air objects radar observation. Also it was shown that the amplitude of UAV dielectric prop is decreased when observation direction changes from its axes of rotation. At the same time the intensity of a prop response can be comparable with the other UAV structural components ones. And so UAV rotor modulation spectrum parameters it useful to investigate for developing algoritms of signal processing that allow effective detection of signal reflected by UAV against a background of passive interferences. Demonstrated results allow estimating the futures of various frequency band radars on detection and tracking of tactical UAVs. Peculiarities of radar scattering characteristics of tactical UAVs at low altitude and artillery shells show advisability on integration of functions of such objects radar observation in single mobile S-band radar.

Keywords: methods of mathematical modeling, radar cross-section, radar, radar visibility, tactical unmanned aerial vehicle. 